\title{
Toxicity, Pathogenicity, and Genetic Differentiation of Five Species of Fusarium from Sorghum and Millet
}

\author{
John F. Leslie, Kurt A. Zeller, Sandra C. Lamprecht, John P. Rheeder, and Walter F. O. Marasas
}

First and second authors: Department of Plant Pathology, Throckmorton Plant Sciences Center, Kansas State University, Manhattan 66506; third author: Plant Protection Research Institute, Agricultural Research Council, Private Bag X5017, Stellenbosch 7600, South Africa; and fourth and fifth authors: PROMEC unit, Medical Research Council, P.O. Box 19070, Tygerberg 7505, South Africa.

Current address of K. A. Zeller: U.S. Department of Agriculture-APHIS-PPQ-CPHST, Plant Germplasm Quarantine and Biotechnology Laboratory, BARC-EAST, Building 580, Beltsville, MA 20705.

Accepted for publication 12 November 2004.

\begin{abstract}
Leslie, J. F., Zeller, K. A., Lamprecht, S. C., Rheeder, J. P., and Marasas, W. F. O. 2005. Toxicity, pathogenicity, and genetic differentiation of five species of Fusarium from sorghum and millet. Phytopathology 95:275-283.

Fusarium isolates recovered from sorghum and millet are commonly identified as $F$. moniliforme, but with the recognition of new species in this group, the strains given this name are being re-evaluated. We analyzed five strains each from five Fusarium species ( $F$. andiyazi, $F$. nygamai, F. pseudonygamai, F. thapsinum, and F. verticillioides) often associated with sorghum and millet for their ability to produce fumonisin and moniliformin, their toxicity to ducklings, and their ability to cause disease on sorghum seedlings in vitro. These species can be distinguished with isozymes (fumarase, NADP-dependent isocitrate dehydrogenase, and malate dehydrogenase) and with banding patterns resulting from ampli-

fied fragment length polymorphisms. Two species, F. pseudonygamai and F. thapsinum, produced high levels of moniliformin, but little or no fumonisins, and were consistently highly toxigenic in the duckling tests. Two species, $F$. verticillioides and $F$. nygamai, produced high levels of fumonisins, but little or no moniliformin, and also were toxigenic in the duckling tests. F. andiyazi produced little or no toxin and was the least toxigenic in the duckling tests. In sorghum seedling pathogenicity tests, $F$. thapsinum was the most virulent followed by $F$. andiyazi, then $F$. verticillioides, and finally F. nygamai and F. pseudonygamai, which were similar to each other. Thus, these five species, which would once have all been called F. moniliforme, differ sufficiently in terms of plant pathogenicity and toxin production profile, that their previous misidentification could explain inconsistencies in the literature and differences observed by researchers who thought they were all working with the same fungal species.
\end{abstract}

Fusarium spp. can cause stalk rots, ear rots, and grain mold, resulting in serious production losses in both maize and sorghum $(12,72)$, and produce mycotoxins that are harmful to both humans and domesticated animals. In high incidence areas of human esophageal cancer in Africa, e.g., portions of the Eastern Cape Province of South Africa, traditional indigenous African staple crops such as sorghum (Sorghum bicolor (L.) Moench) and pearl millet (Pennisetum glaucum (L.) R.Br) have been replaced by maize (Zea mays L.) during the past 50 to 100 years (59). This change in staple diet may have affected the nutritional status of the populations at risk for esophageal cancer and may have altered the kinds and amounts of Fusarium mycotoxins to which these populations are exposed.

Risks associated with Fusarium toxins usually are assessed based on the Fusarium species present, as not all species produce all toxins. Important toxins produced by these fungi include the fumonisins (14) and moniliformin (45). Based on duckling toxicity tests (32) and brine shrimp assays (34), additional mycotoxigenic compounds produced by these fungi probably remain to be identified.

Fusarium spp. from sorghum and millet have only recently become the subject of in depth research and often were included only as isolates of peripheral interest in earlier studies. Modern work on the taxonomy of the genus Fusarium began with Wollenweber and Reinking (74), who established the section Liseola within the genus Fusarium for species that produce microconidia

Corresponding author: J. F. Leslie; E-mail address: jfl@ plantpath.ksu.edu

DOI: 10.1094/PHYTO-95-0275

(c) 2005 The American Phytopathological Society in chains and/or false heads and macroconidia, but that do not produce chlamydospores. A chain-forming Fusarium sp. isolated from moldy maize in Nebraska and described as $F$. moniliforme Sheldon (65) was included in section Liseola by Wollenweber and Reinking (74), with two other species and three varieties, for a total of six taxa. Doidge (9) recognized only two representatives of section Liseola in South Africa, i.e., F. moniliforme with microconidia in chains and F. moniliforme var. subglutinans Wollenw. $\&$ Reinking with microconidia not in chains. All the above taxa were later reduced to a single species, F. moniliforme Sheldon emend. Snyder \& Hansen by Snyder and Hansen (66).

Booth (3) initiated the re-evaluation of the species in section Liseola that is still in progress by separating $F$. moniliforme var. subglutinans from $F$. moniliforme due to the absence of microconidial chains and the presence of polyphialides. Gerlach and Nirenberg (15) expanded the number of taxa in section Liseola to 10 and pointed out that, based on priority, the correct name for $F$. moniliforme is $F$. verticillioides (Sacc.) Nirenberg (50), and the name of the teleomorph is Gibberella moniliformis Wineland (73); a position now generally accepted in the Fusarium research community (64). Nelson et al. (49) accepted four taxa in section Liseola, including $F$. moniliforme and another chain-forming species, F. proliferatum (Matsushima) Nirenberg, which was separated because of the presence of polyphialides. They also elevated F. moniliforme var. subglutinans to species rank as $F$. subglutinans (Wollenw. \& Reinking) Nelson, Toussoun \& Marasas. In the last 20 years, five additional chain-forming Fusarium species in section Liseola have been described; F. andiyazi Marasas, Rheeder, Lamprecht, Zeller \& Leslie (44); F. globosum Rheeder, Marasas \& Nelson (60); F. miscanthi W. Gams et al. (13); F. nisikadoi Aoki \& Nirenberg (51); and F. thapsinum Klittich, Leslie, 
Nelson \& Marasas (26). These taxonomic treatments differed somewhat from each other, but only two of them $(26,44)$ differentiated between $F$. moniliforme (or $F$. verticillioides) from maize and sorghum, whereas some stated explicitly that $F$. moniliforme occurs on both maize and sorghum $(3,9,33,74)$.

These taxonomic difficulties are further complicated by chainforming Fusarium species that resemble those seen in section Liseola, but that also produce chlamydospores (e.g., F. nygamai Burgess \& Trimboli [6] and F. napiforme Marasas, Nelson \& Rabie [42]), which along with $F$. dlamini Marasas, Nelson \& Toussoun (40) were placed in the new section Dlaminia by Kwasna et al. (27). This new section has not been widely used, and instead many members of both sections Liseola and Elegans are now referred to as part of the "Gibberella fujikuroi species complex" (28,30,31). DNA sequence data indicate that section Liseola is paraphyletic and that $F$. nygamai, F. napiforme, and F. dlamini are "phylogenetically nested within section Liseola" (54). The "G. fujikuroi species complex" now contains at least 46 phylogenetically distinct lineages $(54,55)$, including 10 new species described by Nirenberg and O'Donnell (52), two species described by Nirenberg et al. (53), and most recently, $F$. andiyazi (44) and F. konzum Zeller, Summerell \& Leslie (76). At present there are at least 15 described Fusarium species in the "G. fujikuroi complex" that produce microconidia in chains: $F$. andiyazi; $F$. annulatum Bugnicourt; F. brevicatenulatum Nirenberg, O'Donnell, Kroschel \& Andrianavo; F. fujikuroi; F. globosum; F. lactis Pirotta \& Riboni; F. napiforme; F. nygamai; F. phyllophilumi Nirenberg \& O'Donnell; $F$. proliferatum; $F$. pseudoanthophilum Nirenberg, O'Donnell \& Mubutanhema; F. pseudocircinatum O'Donnell \& Nirenberg; F. pseudonygamai O'Donnell \& Nirenberg; F. thapsinum; and $F$. verticillioides, but not all of these have been recovered from sorghum and millets.

In addition to maize and sorghum, Booth (3) stated that F. moniliforme also occurs on rice and sugarcane, is a "major para- site" of several members of the family Gramineae, and occurs on at least 31 other families of plants. This purported host range of F. moniliforme was extended even further by Bacon et al. (1), who calculated that $11,000+$ species of plants could serve as a host for this fungus. In this context, it is not surprising that the fungus that causes "head blight" or "grain mold" of sorghum has been, and often still is, referred to as F. moniliforme and considered to be conspecific with the fungus by the same name associated with ear and stalk rot of maize $(2,11,12,33,47,56-58)$.

Our objective in this study was to evaluate in detail a limited number of strains (five) from each of five taxa ( $F$. andiyazi, $F$. nygamai, $F$. pseudonygamai, $F$. thapsinum, and $F$. verticillioides) commonly recovered from sorghum, millet, and maize in South Africa. Three of these taxa, $F$. verticillioides, $F$. thapsinum, and $F$. nygamai, are relatively well described and understood. The other two, $F$. pseudonygamai and $F$. andiyazi, are more recently described and have not been as extensively characterized. Our working hypothesis is that these five species have commonly been confounded in the past, probably all identified as $F$. moniliforme from sorghum and millet, resulting in the confusingly different toxicological and phytopathogenic properties that are simultaneously attributed to $F$. moniliforme. To distinguish strains and species, we used various genetic and molecular techniques (e.g., sexual crosses [28,30,31], vegetative compatibility [29], isozymes [16], and amplified fragment length polymorphisms [AFLPs] $[42,68,75,76])$ to develop a composite picture of the differences between species that is consistent with differences in economically important traits such as mycotoxin profiles, duckling toxicity, and virulence toward sorghum seedlings.

\section{MATERIALS AND METHODS}

Strains and culture conditions. Twenty-five strains (Table 1) were used in these studies. Strain numbers from collections are

TABLE 1. Strains used in this study

\begin{tabular}{|c|c|c|c|c|c|}
\hline MRC strain ${ }^{y}$ & KSU strain ${ }^{\mathrm{y}}$ & Mating type $z$ & Host & Geographic origin & Reference \\
\hline \multicolumn{6}{|c|}{ Fusarium andiyazi } \\
\hline 5993 & 3860 & $M A T-1$ & Sorghum grain & Greytown, South Africa & 44 \\
\hline 5995 & 3862 & $M A T-1$ & Sorghum grain & Greytown, South Africa & 44 \\
\hline$\underline{6122}$ & $\underline{4804}$ & $M A T-2$ & Sorghum soil debris & Greytown, South Africa & 44 \\
\hline 6123 & $\overline{4812}$ & $M A T-2$ & Sorghum soil debris & Greytown, South Africa & 44 \\
\hline 6126 & 4807 & $M A T-1$ & Sorghum soil debris & Greytown, South Africa & 44 \\
\hline \multicolumn{6}{|l|}{ F. nygamai } \\
\hline 3997 & $\underline{1782}$ & $M A T-1$ & Sorghum root & Narrabri, Australia & 6 \\
\hline$\overline{3998}$ & $\overline{1783}$ & $M A T-1$ & Root debris & Rockhampton, Australia & 6 \\
\hline 4010 & 1795 & $M A T-2$ & Sorghum field soil & Springbok Flats, South Africa & 6 \\
\hline 4011 & 1796 & $M A T-1$ & Sorghum field soil & Springbok Flats, South Africa & 6 \\
\hline 4012 & 1797 & $M A T-1$ & Sorghum field soil & Butterworth, South Africa & 6 \\
\hline \multicolumn{6}{|c|}{ F. pseudonygamai } \\
\hline 1240 & 1762 & $M A T-1$ & Pearl millet grain & Ovambo, Namibia & 43 \\
\hline 1247 & 1765 & $M A T-2$ & Pearl millet grain & Ovambo, Namibia & 43 \\
\hline 2203 & 1767 & $M A T-1$ & Pearl millet grain & Ovambo, Namibia & 43 \\
\hline 4149 & 1801 & $M A T-1$ & Pearl millet grain & Kavango, Namibia & 43 \\
\hline 4150 & 1802 & $M A T-1$ & Pearl millet grain & Kavango, Namibia & 43 \\
\hline \multicolumn{6}{|l|}{ F. thapsinum } \\
\hline 6001 & 3868 & $M A T-2$ & Sorghum root & Kwazulu-Natal, South Africa & 26 \\
\hline 6002 & 3869 & $M A T-2$ & Sorghum root & Kwazulu-Natal, South Africa & 26 \\
\hline 6003 & 3870 & $M A T-2$ & Sorghum root & Kwazulu-Natal, South Africa & 26 \\
\hline 6004 & 3871 & $M A T-2$ & Sorghum root & Kwazulu-Natal, South Africa & 26 \\
\hline 6148 & 3884 & $M A T-1$ & Sorghum seed & Northwest Province, South Africa & 26 \\
\hline \multicolumn{6}{|c|}{ F. verticillioides } \\
\hline 826 & 488 & $M A T-1$ & Maize grain & Transkei, South Africa & 14,32 \\
\hline 1065 & 4796 & $M A T-2$ & Maize grain & Transkei, South Africa & 32 \\
\hline 4315 & 4801 & $M A T-2$ & Maize grain & Transkei, South Africa & 32 \\
\hline 4317 & 4802 & $M A T-1$ & Maize grain & Transkei, South Africa & 32 \\
\hline 4321 & 4803 & $M A T-1$ & Maize grain & Transkei, South Africa & 32 \\
\hline
\end{tabular}

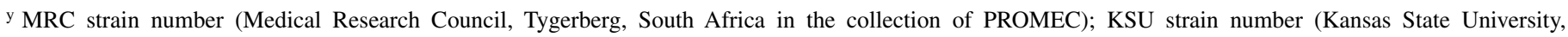
Department of Plant Pathology). Ex-holotype cultures are underlined.

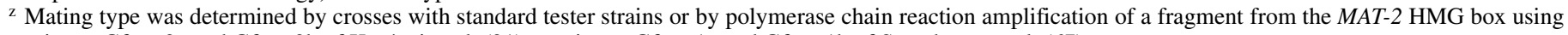
primers Gfmat2a and Gfmat2b of Kerényi et al. (21) or primers Gfmat1a and Gfmat1b of Steenkamp et al. (67). 
denoted as follows: KSU (Kansas State University, Manhattan), MRC (Medical Research Council, Tygerberg), FGSC (Fungal Genetics Stock Center, University of Kansas Medical Center, Kansas City), BBA (Biologische Bundesanstalt für Land-und Forstwirtschaft, Berlin, Germany), and FRC (Fusarium Research Center, Pennsylvania State University, University Park). Two of the F. pseudonygamai strains, MRC 1240 and MRC 2203, are vitamin auxotrophs that required the vitamin mixture of Correll et al. (7) for growth in minimal medium. For AFLP studies, we included the ex-holotype strain of F. pseudonygamai (MRC 7537, KSU X-10762, NRRL 13592, BBA 69552, and FRC M-1166). This strain has a pedigree that indicates it was first collected by one of us as MRC 515 from pearl millet in Namibia $(39,41$, 43,48 ), and assigned to either $F$. moniliforme or $F$. nygamai, but with atypical morphological characters, and does not originate from Nigeria as claimed in the original species description (52). For isozyme studies we also included established mating-type tester strains as comparison standards. We used the following standard G. fujikuroi mating population mating-type tester strains $(22,28,30,36)$ to test for sexual cross-fertility: FGSC 7600 (MATA-1), FGSC 7603 (MATA-2), FGSC 7611 (MATB-1), FGSC 7610 (MATB-2), FGSC 8931 (MATC-1), FGSC 8932 (MATC-2), FGSC 7615 (MATD-1), FGSC 7614 (MATD-2), FGSC 7616 (MATE-1), FGSC 7617 (MATE-2), FGSC 7057 (MATF-1), FGSC 7056 (MATF-2), FGSC 8934 (MATG-1), and FGSC 8933 (MATG-2).

Strains were routinely cultured on carnation leaf agar (10) or on modified Czapek's complete medium (7). Strains were maintained as lyophilized cultures (MRC) or as spore suspensions in $15 \%$ glycerol frozen at $-70^{\circ} \mathrm{C}$ (KSU).

Radial growth rates of all 25 strains were determined by measuring colony diameters of single conidial cultures on potato dextrose agar (Difco Laboratories, Detroit) in 90-mm-diameter petri dishes incubated for $72 \mathrm{~h}$ in total darkness at 25 or $30^{\circ} \mathrm{C}$. Measurements were made on three replicate cultures that each originated from single conidia per temperature for each strain.

Sexual crosses and diagnosis of mating type. We determined the mating type of all 25 strains following polymerase chain reaction (PCR) amplification with the primers of Kerényi et al. (21) or Steenkamp et al. (67). Strains also were crossed with standard mating-type tester strains on carrot agar according to the techniques of Klittich and Leslie (24) for G. thapsina and G. fujikuroi mating populations A to E. Crosses with testers of G. nygamai Klaasen \& Nelson were made by using the tester strains and protocols of Klaasen and Nelson (22). Within F. andiyazi, F. nygamai, and $F$. pseudonygamai, strains were intercrossed in all possible pairwise combinations, with each strain serving as both the male and the female parent in crosses with other members of the group. All crosses were repeated at least twice. Fertile crosses produced perithecia that exuded a cirrus of ascospores.

DNA manipulations. DNA was isolated with a CTAB protocol, as described by Kerényi et al. (21), and stored in $1 \times$ Tris-EDTA (61) at $4^{\circ} \mathrm{C}$ until used. AFLPs were generated essentially as described by Vos et al. (71), with the modifications of Marasas et al. (44), and analyzed as described by Marasas et al. (44) and Zeller et al. (75). In brief, we used two primer pair combinations (EcoRI+TT/MseI+AC and EcoRI+GG/MseI+TG) and analyzed up to 150 bands in intraspecific comparisons and up to 360 bands in the interspecific pairs. The EcoRI primers in the final PCR amplifications were labeled with ${ }^{33} \mathrm{P}$. Labeled DNA fragments were detected by autoradiography following separation on $6 \%$ polyacrylamide gels. AFLP profiles were scored manually for the presence or absence of bands, and genetic similarity was assessed with the Dice coefficient.

Vegetative compatibility tests. Nitrate nonutilizing (nit) mutants were generated from all 25 strains and used in complementation tests to identify strains that belonged to the same vegetative compatibility group (VCG) $(7,24,25)$. The nit mutants were generated on a minimal medium containing $2 \% \mathrm{KClO}_{3}$ and assigned to one of three classes-nit1, nit3, or NitM-based on their ability to grow on media containing differential nitrogen sources (7). F. nygamai strains MRC 4010 and MRC 4012 and F. andiyazi strain MRC 6123 were resistant to $2 \% \mathrm{KClO}_{3}$ but sensitive to $3 \% \mathrm{KClO}_{3}$. Complementary mutants in the same VCG form a prototrophic heterokaryon when cultured together on a minimal medium containing $\mathrm{KNO}_{3}$ as the sole nitrogen source. Whenever possible, a nitl and a NitM mutant pair from each strain was used in the pairing procedure. If phenotypically distinct mutants from the same parental strain could not form a heterokaryon, then the parental strain was designated as heterokaryon self-incompatible (8). Pairings were made in 24-well hybridoma plates as described by Klittich and Leslie (25). All pairings were tested at least twice.

Isozyme phenotype. Isozymes were resolved and isolated on the basis of protein banding patterns in starch gels as described by Huss et al. (16). We tested the isozymes triose phosphate isomerase (TPI), EC 5.3.1.1; NADP-dependent isocitrate dehydrogenase (IDH), EC 1.1.1.42; fumarase (FUM), EC 4.2.1.2; malate dehydrogenase (MDH), EC 1.1.1.37; mannitol dehydrogenase (MADH), EC 1.1.1.67; glucose-6-phosphate dehydrogenase (G6PDH), EC 1.1.1.49; and phosphogluconate dehydrogenase (PGDH), EC 1.1.1.44.

Secondary metabolite production. Fumonisin $\mathrm{B}_{1}$ and $\mathrm{B}_{2}$ contents of cultures grown on patties of ground maize were determined by the method of Sydenham et al. (69) as modified by Leslie et al. (32); detection limit $1 \mu \mathrm{g} / \mathrm{g}$. Moniliformin levels were initially determined by the method of Thiel (70); detection limit $60 \mu \mathrm{g} / \mathrm{g}$. Strains that produced little or no moniliformin in this assay were re-examined using the more sensitive method of Scott and Lawrence (63); detection limit $1 \mu \mathrm{g} / \mathrm{g}$.

Duckling toxicity protocol. All 25 strains were tested for toxicity to ducklings according to the methods of Marasas et al. $(38,46)$ as modified by Leslie et al. $(32)$. The ducklings and their feed were weighed at the beginning of each experiment, and the total feed intake value for each group of four ducklings was calculated from the amount of feed remaining at the end of the test. Mortality was recorded daily, and the mean day of death was calculated from the number of ducklings that died on different days. Cultures were considered toxic if they caused the death of three or four of the four ducklings in a single group. A toxicity index was calculated by multiplying the amount of feed intake, in grams, by the mean day of death to obtain an inverse measure of toxicity for the cultures (19). This test was conducted once with the different strains serving as replicates by which the general toxicity of a species was estimated.

Sorghum pathogenicity assays. Pathogenicity tests were conducted in an agar test tube assay. Strains were assayed for pathogenicity by inoculating seedlings of sorghum cvs. PAN 8560 and PAN 8472. Seed was treated in a water bath at $55^{\circ} \mathrm{C}$ for $30 \mathrm{~min}$ to eliminate seedborne fungi, but we had to increase the length of the heat treatment from $5 \mathrm{~min}$, as described previously $(17,18)$, to 30 min to ensure that all of the endogenous Fusarium propagules were dead. Disinfested seeds were germinated on $0.6 \%$ water agar. After incubation for 14 days, sterile germinated seeds were transferred to test tubes ( 200 by $30 \mathrm{~mm}$ ) containing $20 \mathrm{ml}$ of solidified sterile Hoagland's no. 2 medium (one seed per tube). The tubes were plugged with sterile nonabsorbent cotton and incubated for 10 days with a 14-h photoperiod (Sylvania GroLux, WFS96T12/Gro/QHO WS 215W, GTE Products Corp., Danvers, MA) at $25^{\circ} \mathrm{C}$ by day and $18^{\circ} \mathrm{C}$ by night. Uniform seedlings were selected for inoculation. For each of the 25 Fusarium strains, inoculum was prepared and seedling tubes were inoculated with $0.5 \mathrm{ml}$ of a spore suspension containing $1 \times 10^{6}$ spores per $\mathrm{ml}$ and incubated for 30 additional days under the same conditions as those used for the initial growth of the seedlings. Controls were inoculated with $0.5 \mathrm{ml}$ of sterile potato dextrose broth 
(Difco Laboratories), the medium in which the cultures had been grown. Roots were rated visually for disease severity on a 1 to 5 scale reflecting the proportion of the root system with visual lesions as described by Schreuder et al. (62). The foliage of the seedlings was excised, and shoot and root length was measured. Root and shoot dry mass were determined by weighing after drying at $60^{\circ} \mathrm{C}$ for 3 days.

The experiment was done twice. There were three replicates (blocks) in the first experiment and 12 in the second. The treatment design was a $2 \times 26$ factorial with two cultivars and 26 fungal treatments (one control and five strains from each of the five species). An experimental unit was a single plant. Factorial analysis of variance was performed on the root and shoot length dry mass data. Disease severity ratings were ranked before the data were subjected to analysis of variance (version 6; SAS Institute, Cary, NC) according to the manufacturer's instructions. Student's $t$ test and least significant differences at the 5\% significance level were calculated to compare means.

\section{RESULTS}

Vegetative growth. Radial growth rates for all five taxa (Table 2) were similar at both 25 and $30^{\circ} \mathrm{C}$, ranging from a mean of $25 \mathrm{~mm}$ in $72 \mathrm{~h}$ at either 25 or $30^{\circ} \mathrm{C}$ for $F$. nygamai to $32 \mathrm{~mm}$ in $72 \mathrm{~h}$ at $30^{\circ} \mathrm{C}$ for $F$. andiyazi. Pigmentation of the reverse side of the colony was purple for $F$. andiyazi; white, peach, or purple for $F$. nygamai, $F$. pseudonygamai, and $F$. verticillioides, respectively; and white or yellow for $F$. thapsinum.

Mating type and sexual cross-fertility. Both mating types were observed in all five species (Table 1 ). The $F$. verticillioides and $F$. thapsinum strains were all fertile as males with one of the two standard tester strains for those species. Two of the F. verticil- lioides strains, MRC 826 and MRC 4317, also were fertile as the female parent in a reciprocal cross with the standard tester strains. Strains assigned to $F$. nygamai, $F$. pseudonygamai, or $F$. andiyazi were not cross-fertile with tester strains from $G$. fujikuroi mating populations A to E, G. thapsina, or G. nygamai, and mating-type diagnoses were based on PCR amplification with primers specific for either MAT-1 or MAT-2 $(21,67)$.

Within $F$. nygamai, $F$. pseudonygamai, and $F$. andiyazi, the five strains were crossed in all possible pairwise combinations, but no fertile crosses were observed. We were unable to repeat the cross reported by Klaasen and Nelson (22) in which strain MRC 4011 was reported to be cross-fertile with one of the G. nygamai tester strains; however, we also were unable to obtain a positive control cross between the two G. nygamai tester strains. In crosses with testers from G. fujikuroi mating population B, we found very few fertile perithecia in some crosses with $F$. nygamai strain MRC 4012 and $F$. andiyazi strains MRC 5993 and MRC 6126, and with all of the $F$. pseudonygamai strains. These rare, apparently fertile perithecia were assumed to have resulted from self-fertilization by the tester strains for mating population $\mathrm{B}$, as previously reported (5).

Vegetative compatibility. We tested all five strains from each species (Table 1) for vegetative compatibility with the other strains in that species. We used four independently derived nit mutants from each strain, two nit1 and two NitM, in the pairings. One of the 25 strains tested, F. nygamai MRC 4011, was heterokaryon self-incompatible. All of the other strains were heterokaryon self-compatible. Within each species we found no strains that were in the same VCG, and thus concluded that none of the 25 strains were vegetative clones.

Isozyme polymorphisms. Four isozymes (FUM, IDH, MDH, and TPI) have collectively been used to distinguish G. fujikuroi

TABLE 2. Radial growth rates, toxins produced, and toxicities of strains of Fusarium verticillioides, F. thapsinum, F. nygamai, F. pseudonygamai, and F. andiyazi

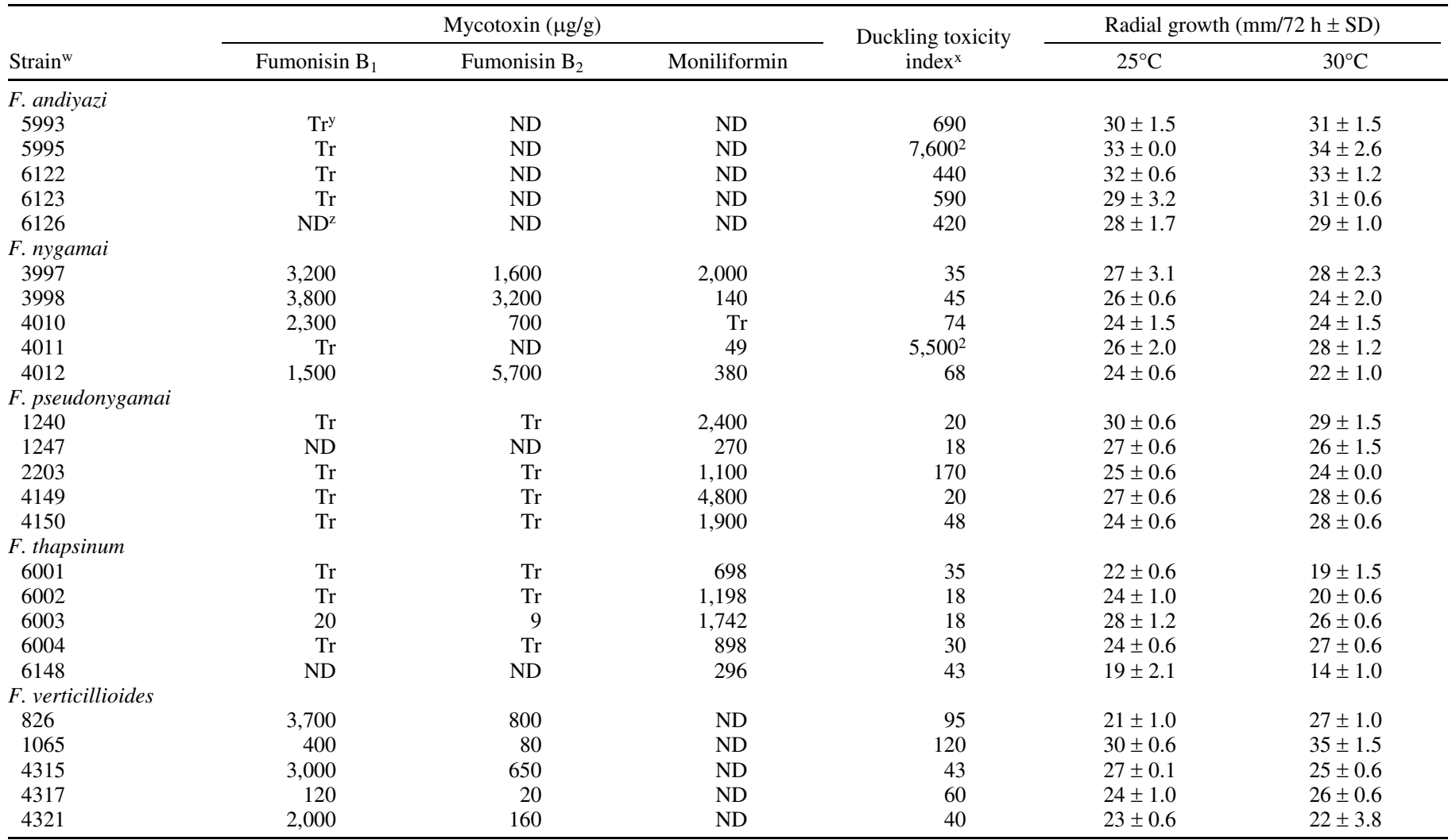

${ }^{\mathrm{w}}$ Strain number from the MRC strain collection.

$\mathrm{x}$ Toxicity index $=$ number of grams of feed consumed $\times$ mean day of death. Thus, the smaller the number, the more toxic the strain. A numerical superscript indicates the number of ducklings that died during the 14-day examination period if that number was less than the total of four.

${ }^{\mathrm{y}} \mathrm{Tr}=$ trace (for fumonisin, 1 to $4 \mu \mathrm{g} / \mathrm{g}$, and for moniliformin, 1 to $5 \mu \mathrm{g} / \mathrm{g}$ ).

${ }^{\mathrm{z}} \mathrm{ND}=$ not detected (for fumonisin, $<1 \mu \mathrm{g} / \mathrm{g}$, and for moniliformin, $<1 \mu \mathrm{g} / \mathrm{g}$ ). 
mating populations A to E, $F$. thapsinum, and $F$. nygamai (16). The profiles for MADH, PGDH, and G6PDH were monomorphic, as previously observed.

For three of the diagnostic isozymes, only previously identified forms were observed. For FUM (Table 3), only the previously described $\alpha$ and $\gamma$ forms were observed, although three of the five F. nygamai strains (MRC 3997, MRC 3998, and MRC 4010) had the $\gamma$ form, which was not detected in the two previously tested strains of this species. For MDH (Table 3), we observed only the previously described $\alpha$ and $\gamma$ forms, with all of the $F$. andiyazi and $F$. pseudonygamai strains having the $\gamma$ form. The five $F$. nygamai strains all had the $\alpha$ form, as reported previously (16). Members of $G$. fujikuroi mating population A have a unique form of TPI $(\beta)$, with the remaining mating populations, including $F$. nygamai, having a faster running $(\alpha)$ form. Both $F$. pseudonygamai and $F$. andiyazi have the $\alpha$ form of TPI.

IDH was the only isozyme for which new forms were observed (Fig. 1; Table 3). For F. andiyazi, only the previously described $\beta$ form was observed. Four of the five $F$. pseudonygamai strains have the previously described $\gamma$ form of IDH, and one strain (MRC 1240) has a new form $(\alpha / \beta)$ that appears to represent a composite of the $\alpha$ and $\beta$ forms previously observed (Table 3). There also are two new forms of IDH not previously observed in $F$. nygamai. One is the previously existing $\beta$ form seen in $F$. verticillioides, F. sacchari, F. fujikuroi, and F. proliferatum, and occasionally in $F$. thapsinum (Table 3 ), which we observed in strain MRC 4012. The other is a new form $(\delta)$ not previously observed in strains from any of the $G$. fujikuroi mating populations, which is intermediate between the previously described $\beta$ and $\omega$ forms, and observed in strain MRC 4011 (Fig. 1).

AFLP polymorphism. We compared banding patterns from the five strains from each species with those from representatives of the other four species and with the ex-holotype strain (MRC

TABLE 3. Isozyme alleles for strains from Fusarium nygamai, F andiyazi, F. pseudonygamai, and the known mating populations of Gibberella fujikuroi

\begin{tabular}{|c|c|c|c|c|}
\hline \multirow[b]{2}{*}{ Strain $^{\mathrm{x}}$} & \multicolumn{4}{|c|}{ Isozyme $^{y}$} \\
\hline & FUM-M & IDH-M & MDH-M & TPI-S6 \\
\hline$F$. andiyazi & $\gamma$ & $\beta$ & $\gamma$ & $\alpha$ \\
\hline $\begin{array}{l}\text { F. nygamai }(3997,3998, \\
\quad 4010,4012)\end{array}$ & $\gamma$ & $\omega$ & $\alpha$ & $\alpha$ \\
\hline F. nygamai (4011) & $\alpha$ & $\delta$ (new) & $\alpha$ & $\alpha$ \\
\hline \multirow{2}{*}{\multicolumn{5}{|c|}{$\begin{array}{l}\text { F. pseudonygamai }(1247,2203 \text {, } \\
4149,4150)\end{array}$}} \\
\hline & $\gamma$ & $\gamma$ & $\gamma$ & $\alpha$ \\
\hline F. pseudonygamai (1240) & $\gamma$ & $\alpha / \beta$ (new) & $\gamma$ & $\alpha$ \\
\hline \multicolumn{5}{|c|}{ G. fujikuroi mating populations ${ }^{\mathrm{z}}$} \\
\hline A (G. moniliformis) & $\alpha$ & $\beta$ & $\alpha$ & $\beta$ \\
\hline $\mathrm{B}($ G. sacchari $)$ & $\alpha$ or $\beta$ & $\beta$ & $\alpha$ & $\alpha$ \\
\hline $\mathrm{C}$ (G. fujikuroi) & $\alpha$ & $\beta$ & $\beta$ & $\alpha$ \\
\hline $\mathrm{D}(G$. intermedia $)$ & $\alpha$ or $\beta$ & $\beta$ & $\beta$ & $\alpha$ \\
\hline $\mathrm{E}(G$. subglutinans $)$ & $\delta$ & $\gamma$ & $\gamma$ & $\alpha$ \\
\hline $\mathrm{F}(G$. thapsina $)$ & $\gamma$ & $\alpha$ or $\beta$ & $\alpha$ & $\alpha$ \\
\hline $\mathrm{G}(G$. nygamai $)$ & $\alpha($ or $\gamma)$ & $\begin{array}{c}\omega \\
(\beta \text { or } \delta \text { or })\end{array}$ & $\alpha$ & $\alpha$ \\
\hline
\end{tabular}

x Strain number from the MRC strain collection, for F. nygamai, F. pseudonygamai and $F$. andiyazi, or the letter designating the mating population of G. fujikuroi.

${ }^{y}$ Isozymes identified from separations in starch gels. The three letters before the dash indicate the isozyme, while the letters and numbers following the dash indicate the buffer. For procedural details, see Huss et al. (16). Isozymes: FUM, fumarase (EC 4.2.1.2); IDH, NADP-dependent isocitrate dehydrogenase (EC 1.1.1.42); $\mathrm{MDH}$, malate dehydrogenase (EC 1.1.1.37); and TPI, triose phosphate isomerase (EC 5.3.1.1). Buffers: M, morpholine and S6, Soltis no. 6. Isozyme forms are the same as those given in Huss et al. (16), except for the IDH forms designated "new", which are reported here for the first time and illustrated in Figure 1.

${ }^{\mathrm{z}}$ Isozyme data for $G$. fujikuroi mating populations A to $\mathrm{G}$ is a composite of the data of Huss et al. (16). The less-common alleles are in parentheses. MP$\mathrm{A}=F$. verticillioides, $\mathrm{MP}-\mathrm{B}=F$. sacchari, $\mathrm{MP}-\mathrm{C}=F$. fujikuroi, $\mathrm{MP}-\mathrm{D}=$ $F$. proliferatum, $\mathrm{MP}-\mathrm{E}=F$. subglutinans, $\mathrm{MP}-\mathrm{F}=F$. thapsinum, and $\mathrm{MP}-\mathrm{G}=$ F. nygamai.
7537) of F. pseudonygamai. Within each of F. andiyazi, F. pseudonygamai, $F$. thapsinum, and $F$. verticillioides, the tested strains were $\geq 73 \%$ similar in AFLP profile (Table 4). The diversity among the $F$. nygamai strains was greater than that observed within the other groups. Strains MRC 3997, 3998, 4010, and 4011 were all $\geq 71 \%$ similar in AFLP fingerprint profile. Strain MRC 4012 was considerably different from the other four $F$. nygamai strains, with similarity ranging from 21 to $26 \%$. These values are comparable to those observed between strains belonging to different species (Table 4) $(34,36,44,68,76)$. Thus, MRC 4012 probably belongs to a species that has not yet been differentiated from F. nygamai. The greatest similarity observed between strains in different species was 33\% for MRC 6148 ( $F$. thapsinum) and MRC 3997 ( $F$. nygamai). Our F. pseudonygamai strains shared $>76 \%$ of their bands with the ex-holotype strain and were $>73 \%$ similar to one another (Table 4). This similarity is the primary reason for our identification of these strains as $F$. pseudonygamai rather than F. nygamai, as had been done previously (46).

Duckling toxicity. With two exceptions (MRC 4011 and MRC 5995), maize cultures of all the Fusarium strains caused the death of four out of four ducklings within 14 days (Table 2). The toxicity index is the number of grams of feed consumed multiplied by the mean day of death. Thus, the smaller the number for the toxicity index, the more toxic the strain. Strains of F. pseudonygamai, $F$. thapsinum, and $F$. verticillioides were the most toxic, because all of the strains had duckling toxicity indices $<170$, i.e., they caused the death of four out of four ducklings in the shortest time and after consumption of the smallest amount of feed. $F$. nygamai probably should be grouped with these three species, but one strain, MRC 4011, caused the death of only two of the four ducklings and consequently had a very high duckling toxicity index $(5,500)$. The least toxic species was $F$. andiyazi with relatively high duckling toxicity indices (420 to 690) for four strains, while one strain, MRC 5995, caused the death of only two of the four ducklings and had the highest duckling toxicity index $(7,600)$ of all the strains tested.

Secondary metabolite production. The mycotoxin profiles of the five Fusarium species with respect to the production of fumonisins $\left(\mathrm{FB}_{1}\right.$ and $\left.\mathrm{FB}_{2}\right)$ and moniliformin agreed relatively well

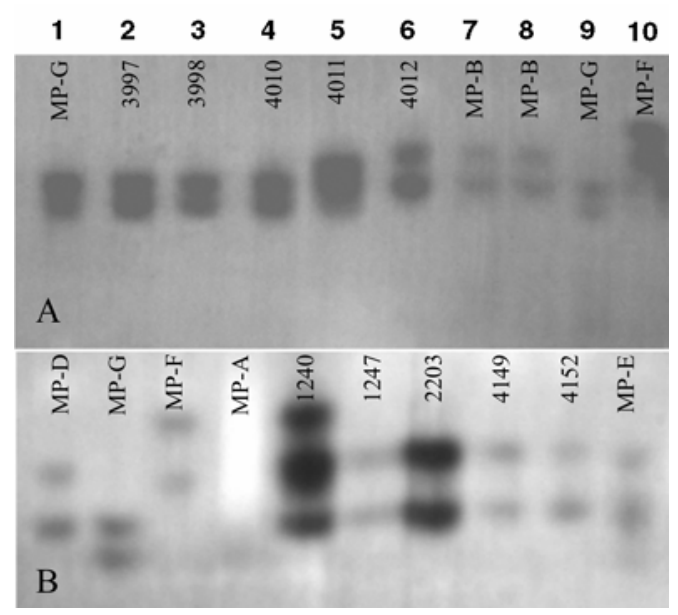

Fig. 1. Resolution of NADP-dependent isocitrate dehydrogenase (EC 1.1.1.42) on starch gels showing new forms identified in this study. A, Lane 1 (Gibberella nygamai FGSC 8934, $\omega$ ), lane 2 (G. nygamai MRC 3997, $\omega$ ), lane 3 (G. nygamai MRC 3998, $\omega)$, lane 4 (G. nygamai MRC 4010, $\omega)$, lane 5 (G. nygamai MRC 4011, $\delta$ ), lane 6 (G. nygamai MRC 4012, $\beta$ ), lane 7 (Fusarium sacchari FGSC 7610, $\beta$ ), lane 8 (F. sacchari FGSC 7611, $\beta$ ), lane 9 (G. nygamai FGSC 8933, $\omega)$, and lane $10(G$. thapsina FGSC $7056, \alpha)$. B, Lane 1 (G. intermedia FGSC 7615, $\beta$ ), lane 2 (G. nygamai FGSC 8934, $\omega$ ), lane 3 (G. thapsina FGSC 7056, $\alpha$ ), lane 4 (missing), lane 5 (F. pseudonygamai MRC 1240, $\alpha / \beta)$, lane 6 (F. pseudonygamai MRC 1247, $\gamma$ ), lane 7 (F. pseudonygamai MRC 2203, $\gamma$ ), lane 8 ( $F$. pseudonygamai MRC 4149, $\gamma$ ), lane 9 (F. pseudonygamai MRC 4152, $\gamma$ ), and lane 10 (G. subglutinans FGSC 7616, $\gamma$ ). 
with their respective toxicity indices (Table 2). Two of the most toxic species ( $F$. thapsinum and $F$. pseudonygamai) also produced the most moniliformin. The high levels of moniliformin (270 to $4,800 \mu \mathrm{g} / \mathrm{g}$ ) produced by all of the strains of these two species probably were responsible for their low toxicity indices and correspondingly high levels of toxicity to ducklings. Some strains of $F$. nygamai also produced relatively high levels of moniliformin (up to $2,000 \mu \mathrm{g} / \mathrm{g}$ ). None of the strains in the least toxic species $(F$. andiyazi) produced any moniliformin.

The highest levels of $\mathrm{FB}_{1}$ were produced by $F$. verticillioides, ranging from 120 to $3,700 \mu \mathrm{g} / \mathrm{g}$, and $F$. nygamai, ranging from 1,500 to $3,800 \mu \mathrm{g} / \mathrm{g}$. The highest $\mathrm{FB}_{2}$ producer was $F$. nygamai (ND-5,700 $\mu \mathrm{g} / \mathrm{g}$ ) followed by $F$. verticillioides $(20$ to $800 \mu \mathrm{g} / \mathrm{g}$ ). The ratios of $\mathrm{FB}_{1} / \mathrm{FB}_{2}$ produced by $F$. verticillioides were 4.6 to $12.5 / 1$ compared with 0.3 to $3.3 / 1$ for $F$. nygamai. One strain of F. nygamai (MRC 4012) produced more $\mathrm{FB}_{2}$ than $\mathrm{FB}_{1}$. Strains of $F$. thapsinum produced, at most, traces of $\mathrm{FB}_{1}$ or $\mathrm{FB}_{2}$, and none of the strains of $F$. andiyazi and $F$. pseudonygamai produced any detectable fumonisins.

Sorghum pathogenicity. Strains of all five Fusarium taxa were pathogenic to sorghum seedlings, as indicated by disease severity rank means that were significantly higher $(P<0.05)$ than the uninoculated control (Table 5). Based on mean values, $F$. andiyazi was significantly more virulent to the seedlings than were $F$. verticillioides, $F$. nygamai, and $F$. pseudonygamai with respect to disease severity, root length, shoot length, and root dry mass. However, $F$. andiyazi was significantly less virulent to sorghum than $F$. thapsinum, with respect to all of these parameters as well as root dry mass.

\section{DISCUSSION}

Differentiating Fusarium spp. in the G. fujikuroi species complex is difficult without relying on DNA-based techniques (35,
68). The five taxa examined in this study were first separated on the basis of morphology with the molecular data collected later to support the tentative differentiation of these groups. We have proposed $(34,36,44,68,76)$ that strains sharing $\geq 65 \%$ of their AFLP bands are conspecific, and that those sharing $\leq 40 \%$ definitely are not. In at least two cases, i.e., the $\mathrm{C}$ and $\mathrm{D}$ mating populations of G. fujikuroi (36) and lineages 6 and 7 of $G$. zeae (20), in which the AFLP similarities are $>40 \%$ but $<65 \%$, members of the different groups retain some cross-fertility. We used the 40 and $65 \%$ similarity cutoffs to identify our strains of F. pseudonygamai to species through a comparison with the ex-holotype strain. Based on AFLPs, all of the groups of strains we worked with are single species, except for $F$. nygamai. Our five $F$. nygamai strains probably represent two species, because MRC 4012 is $<26 \%$ similar to the other four $F$. nygamai strains. Our inability to obtain fertile crosses even with the G. nygamai mating-type tester strains made it impossible for us to test whether this strain belonged to the same biological species, and we suggest that $F$. nygamai as described by Burgess and Trimboli (6) is heterogeneous, i.e., MRC 4012 probably is a member of a cryptic species that has yet to be clearly separated from $F$. nygamai.

Methods other than AFLPs also could be used to distinguish these species. DNA sequences suffice to distinguish these species $(44,54,55,76)$, with portions of the genes encoding $\beta$-tubulin $(t u b)$ and translocation elongation factor $1-\alpha$ (tef) the most commonly analyzed sequences. Isozymes were used previously to separate F. verticillioides, $F$. nygamai, and $F$. thapsinum (16). Both $F$. andiyazi and F. pseudonygamai have $\gamma$ alleles for FUM and $\mathrm{MDH}$, a pattern that is thus far unique to them. These two species can be distinguished based on their IDH alleles, for which $F$. andiyazi has the $\beta$ allele and F. pseudonygamai has either the $\gamma$ allele or a unique $\alpha / \beta$ allele. Until female-fertile strains are identified, probably in a larger population-based study of these species, and mating-type tester strains are synthesized, sexual crosses for

TABLE 4. Amplified fragment length polymorphism (AFLP) similarities between the strains of Fusarium andiyazi, F. nygamai, F. pseudonygamai, F. thapsinum, and $F$. verticillioides ${ }^{\mathrm{w}}$

\begin{tabular}{|c|c|c|c|c|c|c|c|c|c|c|}
\hline Strain $^{x}$ & $6122^{y}$ & $3997^{y}$ & 6001 & 1247 & $7537^{y}$ & 826 & & & & \\
\hline$F$. andiyazi & & & & & & & 5993 & 5995 & 6123 & 6126 \\
\hline 5993 & $0.926^{\mathrm{z}}$ & 0.255 & 0.207 & 0.289 & 0.265 & 0.198 & 1.000 & $\ldots$ & $\ldots$ & $\ldots$ \\
\hline 5995 & 0.947 & 0.236 & 0.207 & 0.289 & 0.245 & 0.198 & 0.936 & 1.000 & $\ldots$ & $\ldots$ \\
\hline 6123 & 0.957 & 0.236 & 0.224 & 0.289 & 0.245 & 0.198 & 0.915 & 0.968 & 1.000 & $\ldots$ \\
\hline 6126 & 0.957 & 0.239 & 0.206 & 0.292 & 0.247 & 0.178 & 0.968 & 0.946 & 0.968 & 1.000 \\
\hline F. nygamai & & & & & & & 3998 & 4010 & 4011 & 4012 \\
\hline 3998 & 0.286 & 0.724 & 0.246 & 0.281 & 0.209 & 0.278 & 1.000 & $\ldots$ & $\ldots$ & $\ldots$ \\
\hline 4010 & 0.252 & 0.763 & 0.305 & 0.305 & 0.264 & 0.283 & 0.756 & 1.000 & $\ldots$ & $\ldots$ \\
\hline 4011 & 0.250 & 0.721 & 0.306 & 0.245 & 0.242 & 0.283 & 0.714 & 0.796 & 1.000 & $\ldots$ \\
\hline 4012 & 0.170 & 0.231 & 0.202 & 0.185 & 0.183 & 0.255 & 0.262 & 0.212 & 0.208 & 1.000 \\
\hline F. pseudonygamai & & & & & & & 1240 & 2203 & 4149 & 4152 \\
\hline 1240 & 0.262 & 0.265 & 0.207 & 0.900 & 0.889 & 0.272 & 1.000 & $\ldots$ & $\ldots$ & $\ldots$ \\
\hline 2203 & 0.235 & 0.222 & 0.212 & 0.827 & 0.819 & 0.265 & 0.881 & 1.000 & $\ldots$ & $\ldots$ \\
\hline 4149 & 0.304 & 0.262 & 0.234 & 0.766 & 0.779 & 0.227 & 0.921 & 0.735 & 1.000 & $\ldots$ \\
\hline 4150 & 0.247 & 0.214 & 0.222 & 0.848 & 0.740 & 0.280 & 0.902 & 0.816 & 0.753 & 1.000 \\
\hline F. thapsinum & & & & & & & 6002 & 6003 & 6004 & 6148 \\
\hline 6002 & 0.220 & 0.704 & 0.980 & 0.216 & 0.214 & 0.271 & 1.000 & $\ldots$ & $\ldots$ & $\ldots$ \\
\hline 6003 & 0.220 & 0.704 & 0.980 & 0.216 & 0.214 & 0.271 & 1.000 & 1.000 & $\ldots$ & $\ldots$ \\
\hline 6004 & 0.220 & 0.704 & 0.980 & 0.216 & 0.214 & 0.271 & 1.000 & 1.000 & 1.000 & $\ldots$ \\
\hline 6148 & 0.252 & 0.676 & 0.736 & 0.190 & 0.170 & 0.263 & 0.748 & 0.748 & 0.748 & 1.000 \\
\hline$F$. verticillioides & & & & & & & 1065 & 4315 & 4317 & 4321 \\
\hline 1065 & 0.189 & 0.255 & 0.265 & 0.309 & 0.286 & 0.857 & 1.000 & $\ldots$ & $\ldots$ & $\ldots$ \\
\hline 4315 & 0.196 & 0.243 & 0.253 & 0.277 & 0.253 & 0.932 & 0.813 & 1.000 & $\ldots$ & $\ldots$ \\
\hline 4317 & 0.196 & 0.224 & 0.274 & 0.255 & 0.232 & 0.909 & 0.835 & 0.909 & 1.000 & $\ldots$ \\
\hline 4321 & 0.182 & 0.233 & 0.286 & 0.289 & 0.264 & 0.952 & 0.828 & 0.905 & 0.905 & 1.000 \\
\hline
\end{tabular}

${ }^{\mathrm{w}}$ Comparisons in which the two strains share $<40 \%$ of the bands in the AFLP fingerprints are shown with a shaded background.

${ }^{x}$ MRC strain number.

${ }^{y}$ MRC 6122, MRC 7537, and MRC 3997 are ex-holotype strains of F. andiyazi, F. pseudonygamai, and F. nygamai, respectively.

${ }^{\mathrm{z}}$ Similarity was calculated as the Dice coefficient of pairwise distances between each strain. 
identifying these species will not be possible. Until then, we anticipate that most workers will encounter difficulty if using only the described morphological features to distinguish these species.

Strains from seven of the known mating populations in the $G$. fujikuroi species complex have been recovered from sorghum, although the $\mathrm{F}$ mating population ( $F$. thapsinum) usually dominates $(26,30,37)$. Thus far, $F$. andiyazi has been recovered from sorghum in Ethiopia, Nigeria, South Africa, and the United States (44). Some of the "sterile" isolates recovered by Mansuetus et al. (37) from Tanzania and the unusual isolates of $F$. nygamai from Nigeria, Lesotho, and Zimbabwe (56-58), which were not crossfertile with the $G$. moniliformis, $G$. thapsinum, or $G$. nygamai testers (23), also could be $F$. andiyazi. We know less about the geographic distribution of $F$. pseudonygamai, but the five strains used in this study originated from pearl millet grain in Namibia (43), and we have identified isolates of this species from maize in the United States and from sorghum and pearl millet from Mali and Nigeria (J. F. Leslie and K. A. Zeller, unpublished data).

All five of the species we examined occur in Africa, with $F$. verticillioides common on maize, $F$. thapsinum and $F$. andiyazi on sorghum, and F. pseudonygamai on pearl millet. F. proliferatum, which can make both fumonisins and moniliformin, also occurs in Africa and can be recovered from maize, sorghum, and millet. Much of the previous literature referring to $F$. moniliforme from sorghum and millet probably refers to $F$. thapsinum, $F$. andi$y a z i$, and/or $F$. pseudonygamai, and not to the sibling species $F$. verticillioides. Of these three sorghum and millet fungi, none produce high levels of fumonisins, two ( $F$. thapsinum and $F$. pseudonygamai) produce high levels of moniliformin, and one ( $F$. andiyazi) produces no more than a trace of either of these toxins. Thus, subsistence level farmers relying on sorghum or millet as their primary food are much more likely to encounter high levels of moniliformin in their diet, while those that rely on maize are more likely to encounter high levels of fumonisins (because $F$. verticillioides is the dominant Fusarium species on maize). Significant human health problems have not been convincingly associated with moniliformin, but this compound is toxic to animals such as ducklings, rats, mice, chickens, and swine $(38,39)$.

In contrast with the animal toxicity data, the $F$. andiyazi strains caused significantly more disease on sorghum than did the $F$. nygamai and $F$. pseudonygamai strains. $F$. nygamai is not commonly regarded as an economically important plant pathogen, although it has been reported to cause reduction in levels of the parasitic weed Striga hermonthica in sorghum (4). Strains of F. nygamai parasitic to Striga asiatica were described as F. brevicatenulatum (53), and these strains of $F$. nygamai could belong to $F$. brevicatenulatum and not to $F$. nygamai. Our pathogenicity

TABLE 5. Disease severity and root and shoot length and dry mass of sorghum seedlings inoculated with strains of Fusarium thapsinum, F. andiyazi, F. verticillioides, F. nygamai, and F. pseudonygamai

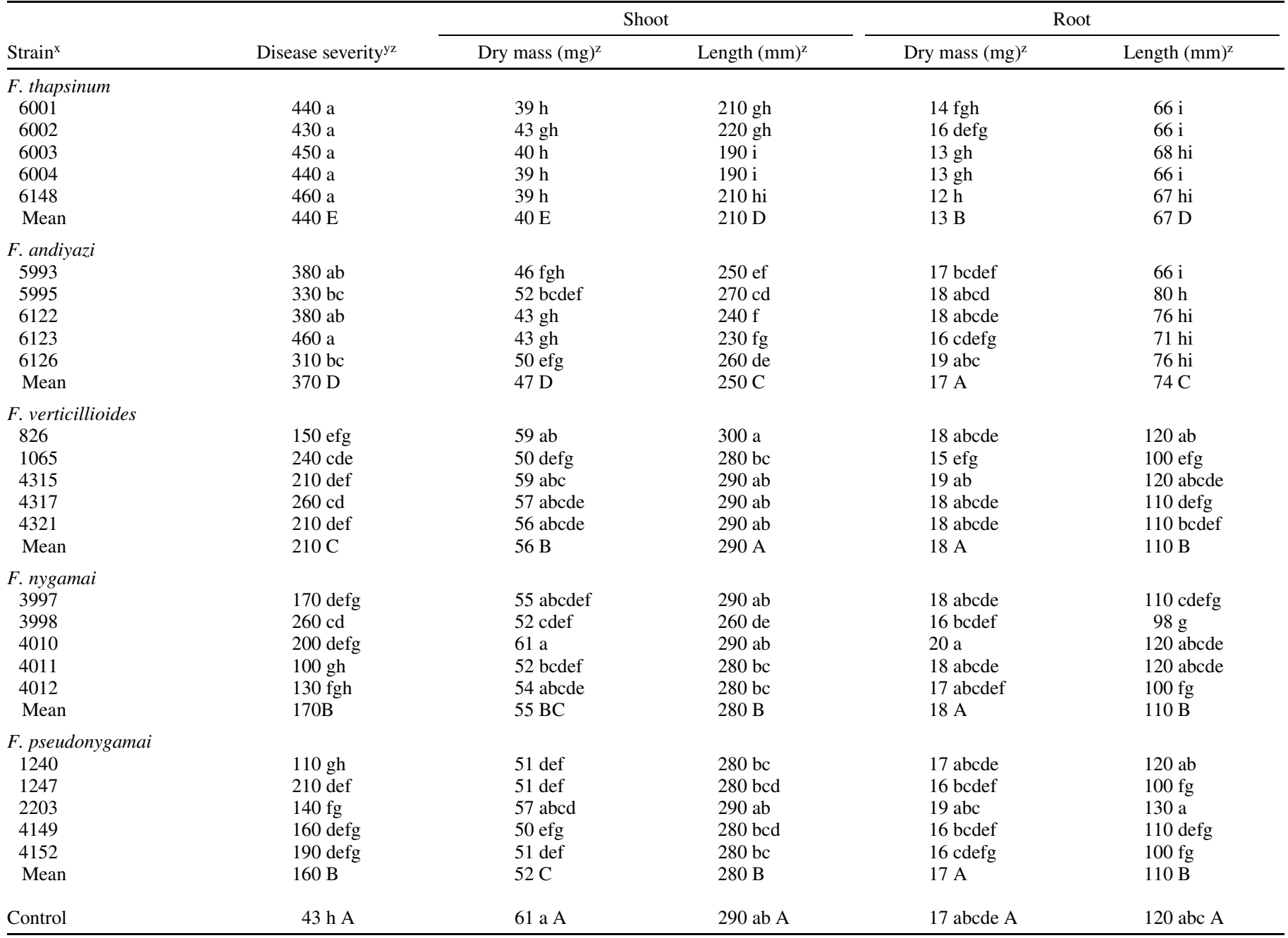

${ }^{\mathrm{x}} \mathrm{MRC}$ strain number.

y Rank mean.

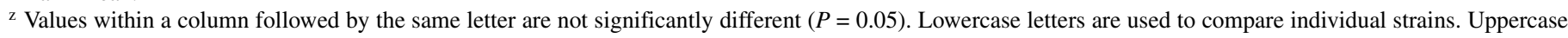
letters are used to compare means of species. 
tests showed that $F$. thapsinum $>F$. andiyazi $>F$. verticillioides $>$ $F$. nygamai $=F$. pseudonygamai with respect to disease on sorghum seedlings. These results are somewhat different from those of Jardine and Leslie (17), who used 11 strains of $F$. thapsinum and two strains of $F$. verticillioides but found no significant differences in the ability of these strains to induce disease following stalk rot inoculation of mature sorghum plants. F. thapsinum probably is the major Fusarium pathogen of sorghum, but $F$. andiyazi and $F$. verticillioides also may be important when they colonize sorghum. F. andiyazi might be associated with other Fusarium-related diseases of sorghum, e.g., grain mold, in which F. thapsinum perhaps plays a minor role. F. nygamai and $F$. pseudonygamai also caused more disease than that observed in the control, but until more distribution data is published, the importance of these species under field conditions will be difficult to critically evaluate. Further studies, preferably with both greenhouse and field tests, however, will be needed to confirm these results.

Jardine and Leslie $(17,18)$ had problems with cross-contamination when conducting pathogenicity tests with $F$. thapsinum and $F$. verticillioides on mature maize and sorghum plants. This crosscontamination is likely the result of the normal endophytic colonization of these plants by various Fusarium spp. One of the biggest problems encountered when screening maize and sorghum for resistance/sensitivity to Fusarium spp. is ensuring that the disease observed is due to the strain(s) that was inoculated and not to those already asymptomatically present in the plant. The test tube assay may be one means of circumventing this problem, if the ratings obtained in this study are predictive of those obtained from studies with mature plants, and could allow comparisons between strains and a more rapid assessment of sensitivity/resistance to the diseases caused by these fungi.

In conclusion, we think that the recognition of different species within the G. fujikuroi species complex from sorghum and millet will make evaluation of the plant pathological and human health risks posed by these fungi, both individually and collectively, much easier to discern. Additional work is needed, especially with $F$. andiyazi and F. pseudonygamai, to confirm the breadth of their distribution, to determine their host preferences and mycotoxin profiles, to develop good mating-type tester strains and identify the teleomorph, and to provide breeders with the strains they need to rigorously challenge their material.

\section{ACKNOWLEDGMENTS}

Contribution no. 03-61-J from the Kansas Agricultural Experiment Station, Manhattan. This research was supported in part by the Kansas Agricultural Experiment Station and by the Sorghum and Millet Collaborative Research Support Program (INTSORMIL) AID/DAN-1254-G00-0021-00 from the U.S. Agency for International Development. We thank F. Calitz for the statistical analysis of the pathogenicity tests; T. Leukes and J. Seier for assistance with the duckling toxicity tests; and A. Clouse, A. Byers, and M. Dalby for assistance with the isozyme and AFLP assays.

\section{LITERATURE CITED}

1. Bacon, C. W., Porter, J. K., Norred, W. P., and Leslie, J. F. 1996. Production of fusaric acid by Fusarium species. Appl. Environ. Microbiol. 62:4039-4043.

2. Bhat, R. V., Shetty, P. H., Amruth, R. P., and Sudershan, R. V. 1997. A foodborne outbreak due to the consumption of moldy sorghum and maize containing fumonisin mycotoxins. Clin. Toxicol. 35:249-255.

3. Booth, C. 1971. The Genus Fusarium. Commonwealth Mycological Institute, Kew, UK

4. Brayford, D. 1997. Fusarium nygamai. No. 1327 in: IMI Descriptions of Fungi and Bacteria. Int. Mycol. Inst., Kew, UK.

5. Britz, H., Coutinho, T. A., Wingfield, M. J., Marasas, W. F. O., Gordon, T. R., and Leslie, J. F. 1999. Fusarium subglutinans f. sp. pini represents a distinct mating population in the Gibberella fujikuroi species complex. Appl. Environ. Microbiol. 65:1198-1201.
6. Burgess, L. W., and Trimboli, D. 1986. Characterization and distribution of Fusarium nygamai sp. nov. Mycologia 78:223-229.

7. Correll, J. C., Klittich, C. J. R., and Leslie, J. F. 1987. Nitrate nonutilizing mutants of Fusarium oxysporum and their use in vegetative compatibility tests. Phytopathology 77:1640-1646.

8. Correll, J. C., Klittich, C. J. R., and Leslie, J. F. 1989. Heterokaryon selfincompatibility in Gibberella fujikuroi (Fusarium moniliforme). Mycol. Res. 93:21-27.

9. Doidge, E. M. 1938. Some South African Fusaria. Bothalia 3:331-483.

10. Fisher, N. L., Burgess, L. W., Toussoun, T. A., and Nelson, P. E. 1982. Carnation leaves as a substrate and for preserving cultures of Fusarium species. Phytopathology 72:151-153.

11. Forbes, G. A., Bandyopadhyay, R., and Garcia, G. 1992. A review of sorghum grain mold. Pages 265-272 in: Sorghum and Millets Diseases: A Second World Review. W. A. J. de Milliano, R. A. Frederiksen, and G. D. Bengston, eds. ICRISAT, Patancheru, India.

12. Frederiksen, R. A., and Odvody, G. N. (eds.) 2000. Compendium of Sorghum Diseases. 2nd ed. The American Phytopathological Society, St. Paul, MN.

13. Gams, W., Klamer, M., and O'Donnell, K. 1999. Fusarium miscanthi sp. nov. from Miscanthus litter. Mycologia 91:263-268.

14. Gelderblom, W. C. A., Jaskiewicz, K., Marasas, W. F. O., Thiel, P. G., Horak, R. M., Vleggaar, R., and Kriek, N. P. J. 1988. Fumonisins-Novel mycotoxins with cancer-promoting activity produced by Fusarium moniliforme. Appl. Environ. Microbiol. 54:1806-1811.

15. Gerlach, W., and Nirenberg, H. I. 1982. The genus Fusarium-A pictorial atlas. Mitt. Biol. Bundesanst. Land- Forstwirtsch. Berl.-Dahl. 209:1-406.

16. Huss, M. J., Campbell, C. L., Jennings, D. B., and Leslie, J. F. 1996. Isozyme variation among biological species in the Gibberella fujikuroi species complex (Fusarium section Liseola). Appl. Environ. Microbiol. 62:3750-3756.

17. Jardine, D. J., and Leslie, J. F. 1992. Aggressiveness of Gibberella fujikuroi (Fusarium moniliforme) isolates to grain sorghum under greenhouse conditions. Plant Dis. 76:897-900.

18. Jardine, D. J., and Leslie, J. F. 1999. Aggressiveness to mature maize plants of Fusarium strains differing in ability to produce fumonisins. Plant Dis. 83:690-693.

19. Jeschke, N., Nelson, P. E., and Marasas, W. F. O. 1987. Toxicity to ducklings of Fusarium moniliforme isolated from corn intended for use in poultry feed. Poultry Sci. 66:1619-1623.

20. Jurgenson, J. E., Bowden, R. L., Zeller, K. A., Leslie, J. F., Alexander, N. J., and Plattner, R. D. 2002. A genetic map of Gibberella zeae (Fusarium graminearum). Genetics 160:1452-1460.

21. Kerényi, Z., Zeller, K. A., Hornok, L., and Leslie, J. F. 1999. Molecular standardization of mating type terminology in the Gibberella fujikuroi species complex. Appl. Environ. Microbiol. 65:4071-4076.

22. Klaasen, J. A., and Nelson, P. E. 1996. Identification of a mating population, Gibberella nygamai sp. nov., within the Fusarium nygamai anamorph. Mycologia 88:965-969.

23. Klaasen, J. A., and Nelson, P. E. 1998. Identity of Fusarium nygamai isolates with long and short microconidial chains from millet, sorghum and soil in Africa. Mycopathologia 140:171-176.

24. Klittich, C. J. R., and Leslie, J. F. 1988. Nitrate reduction mutants of Fusarium moniliforme (Gibberella fujikuroi). Genetics 118:417-423.

25. Klittich, C. J. R., and Leslie, J. F. 1988. Multi-well plates for complementation tests of Fusarium. Fung. Genet. Newsl. 35:21-22.

26. Klittich, C. J. R., Leslie, J. F., Nelson, P. E., and Marasas, W. F. O. 1997. Fusarium thapsinum (Gibberella thapsina): A new species in section Liseola from sorghum. Mycologia 89:643-652.

27. Kwasna, H., Chelkowski, J., and Zajkowski, P. 1991. Grzyby (Mycota), tom XXII. Sierpik (Fusarium). Polska Akademia Nauk, Flora Polska, Warsaw, Poland.

28. Leslie, J. F. 1991. Mating populations in Gibberella fujikuroi (Fusarium section Liseola). Phytopathology 81:1058-1060.

29. Leslie, J. F. 1993. Fungal vegetative compatibility. Annu. Rev. Phytopathol. 31:127-150.

30. Leslie, J. F. 1995. Gibberella fujikuroi: Available populations and variable traits. Can. J. Bot. 73(Suppl. 1):S282-S291.

31. Leslie, J. F. 1999. Genetic status of the Gibberella fujikuroi species complex. Plant Pathol. J. 15:259-269.

32. Leslie, J. F., Marasas, W. F. O., Shephard, G. S., Sydenham, E. W., Stockenström, S., and Thiel, P. G. 1996. Duckling toxicity and the production of fumonisin and moniliformin by isolates in the A and F mating populations of Gibberella fujikuroi. Appl. Environ. Microbiol. 62:11821187.

33. Leslie, J. F., Pearson, C. A. S., Nelson, P. E., and Toussoun, T. A. 1990. Fusarium spp. from corn, sorghum, and soybean fields in the Central and Eastern United States. Phytopathology 80:343-350.

34. Leslie, J. F., Zeller, K. A., Logrieco, A., Mulè, G., Moretti, A., and Ritieni, A. 2004. Species diversity of and toxin production by strains from the 
Gibberella fujikuroi species complex isolated from native prairie grasses in Kansas. Appl. Environ. Microbiol. 70:2254-2262.

35. Leslie, J. F., Zeller, K. A., and Summerell, B. A. 2001. Icebergs and species in populations of Fusarium. Physiol. Mol. Plant Pathol. 59:107117.

36. Leslie, J. F., Zeller, K. A., Wohler, M., and Summerell, B. A. 2004. Interfertility of two mating populations in the Gibberella fujikuroi species complex. Eur. J. Plant Pathol. 110:611-618.

37. Mansuetus, A. S. B., Odvody, G. N., Frederiksen, R. A., and Leslie, J. F. 1997. Biological species of Gibberella fujikuroi (Fusarium section Liseola) recovered from sorghum in Tanzania. Mycol. Res. 101:815820 .

38. Marasas, W. F. O., Kriek, N. P. J., Wiggins, V. M., Steyn, P. S., Towers, D. K., and Hastie, T. J. 1979. Incidence, geographical distribution, and toxigenicity of Fusarium species in South African corn. Phytopathology 69:1181-1185.

39. Marasas, W. F. O., Nelson, P. E., and Toussoun, T. A. 1984. Toxigenic Fusarium Species. The Pennsylvania State University Press, University Park.

40. Marasas, W. F. O., Nelson, P. E., and Toussoun, T. A. 1985. Fusarium dlamini, a new species from southern Africa. Mycologia 77:971-975.

41. Marasas, W. F. O., Nelson, P. E., and Toussoun, T. A. 1988. Reclassification of two important moniliformin-producing strains of Fusarium, NRRL 6022 and NRRL 6322. Mycologia 80:407-410.

42. Marasas, W. F. O., Rabie, C. J., Lübben, A., Nelson, P. E., Toussoun, T. A., and van Wyk, P. S. 1987. Fusarium napiforme, a new species from millet and sorghum in southern Africa. Mycologia 79:910-914.

43. Marasas, W. F. O., Rabie, C. J., Lübben, A. L., Nelson, P. E., Toussoun, T. A., and van Wyk, P. S. 1988. Fusarium nygamai from millet in southern Africa. Mycologia 80:263-266.

44. Marasas, W. F. O., Rheeder, J. P., Lamprecht, S. C., Zeller, K. A., and Leslie, J. F. 2001. Fusarium andiyazi sp. nov., a new species from sorghum. Mycologia 93:1203-1210.

45. Marasas, W. F. O., Thiel, P. G., Rabie, C. J., Nelson, P. E., and Toussoun, T. A. 1986. Moniliformin production in Fusarium section Liseola. Mycologia 78:242-247.

46. Marasas, W. F. O., Thiel, P. G., Sydenham, E. W., Rabie, C. J., Lübben, A., and Nelson, P. E. 1991. Toxicity and moniliformin production by four recently described species of Fusarium and two uncertain taxa. Mycopathologia 113:191-197.

47. Moretti, A., Bennett, G. A., Logrieco, A., Bottalico, A., and Beremand, M. N. 1995. Fertility of Fusarium moniliforme from maize and sorghum related to fumonisin production in Italy. Mycopathologia 131:25-29.

48. Nelson, P. E., Plattner, R. D., Shackelford, D. D., and Desjardins, A. E. 1992. Fumonisin $\mathrm{B}_{1}$ production by Fusarium species other than $F$. moniliforme in section Liseola and by some related species. Appl. Environ. Microbiol. 58:984-989.

49. Nelson, P. E., Toussoun, T. A., and Marasas, W. F. O. 1983. Fusarium Species: An Illustrated Manual for Identification. Pennsylvania State University Press, University Park.

50. Nirenberg, H. I. 1976. Untersuchungen über die morphologische und biologische Differenzierung in der Fusarium-Sektion Liseola. Mitt. Biol. Bundesanst. Land- Forstwirtsch. Berl.-Dahl. 169:1-117.

51. Nirenberg, H. I., and Aoki, T. 1997. Fusarium nisikadoi, a new species from Japan. Mycoscience 38:329-333.

52. Nirenberg, H. I., and O'Donnell, K. 1998. New Fusarium species and combinations within the Gibberella fujikuroi species complex. Mycologia 90:434-458.

53. Nirenberg, H. I., O’Donnell, K., Kroschel, J., Andrianaivo, A. P., Frank, J. M., and Mubatanhema, W. 1998. Two new species of Fusarium: Fusarium brevicatenulatum from the noxious weed Striga asiatica in Madagascar and Fusarium pseudoanthophilum from Zea mays in Zimbabwe. Mycologia 90:459-464.

54. O’Donnell, K., Cigelnik, E., and Nirenberg, H. I. 1998. Molecular systematics and phylogeography of the Gibberella fujikuroi species complex. Mycologia 90:465-493.
55. O’Donnell, K., Nirenberg, H. I., Aoki, T., and Cigelnik, E. 2000. A multigene phylogeny of the Gibberella fujikuroi species complex: Detection of additional phylogenetically distinct species. Mycoscience 41:61-78.

56. Onyike, N. B. N., and Nelson, P. E. 1992. Fusarium species associated with sorghum grain from Nigeria, Lesotho, and Zimbabwe. Mycologia 84:452-458.

57. Onyike, N. B. N., and Nelson, P. E. 1993. The distribution of Fusarium species in soils planted to millet and sorghum in Lesotho, Nigeria and Zimbabwe. Mycopathologia 121:105-114.

58. Onyike, N. B. N., Nelson, P. E., and Marasas, W. F. O. 1991. Fusarium species associated with millet grain from Nigeria, Lesotho and Zimbabwe. Mycologia 83:708-712.

59. Rheeder, J. P., Marasas, W. F. O., Farina, M. P. W., Thompson, G. R., and Nelson, P. E. 1994. Soil fertility factors in relation to esophageal cancer risk in areas in Transkei, southern Africa. Eur. J. Can. Prevent. 3:49-56.

60. Rheeder, J. P., Marasas, W. F. O., and Nelson, P. E. 1996. Fusarium globosum, a new species from corn in southern Africa. Mycologia 88:509-513.

61. Sambrook, J., Fritsch, E. F., and Maniatis, T. 1989. Molecular Cloning: A Laboratory Manual. 2nd ed. Cold Spring Harbor Laboratory, Cold Spring Harbor, NY

62. Schreuder, W., Lamprecht, S. C., Marasas, W. F. O., and Calitz, F. J. 1995 Pathogenicity of three Fusarium species associated with asparagus decline in South Africa. Plant Dis. 79:177-181.

63. Scott, P. M., and Lawrence, G. A. 1987. Liquid chromatographic determination and stability of the Fusarium mycotoxin moniliformin in cereal grains. J. Assoc. Off. Anal. Chem. 10:850-853.

64. Seifert, K. A., Aoki, T., Baayen, R. P., Brayford, D., Burgess, L. W., Chulze, S., Gams, W., Geiser, D., de Gruyter, J., Leslie, J. F., Logrieco, A., Marasas, W. F. O., Nirenberg, H. I., O’Donnell, K., Rheeder, J. P., Samuels, G. J., Summerell, B. A., Thrane, U., and Waalwijk, C. 2003. The name Fusarium moniliforme should no longer be used. Mycol. Res. 107:643-644.

65. Sheldon, J. L. 1904. A corn mold (Fusarium moniliforme n. sp.). Pages 23-32 in: 17th Annual Report. Nebr. Agric. Exp. Stn.

66. Snyder, W. C., and Hansen, H. M. 1945. The species concept in Fusarium with reference to Discolor and other sections. Am. J. Bot. 32:657-666.

67. Steenkamp, E. T., Wingfield, B. D., Coutinho, T. A., Zeller, K. A. Wingfield, M. J., Marasas, W. F. O., and Leslie, J. F. 2000. PCR-based identification of MAT-1 and MAT-2 in the Gibberella fujikuroi species complex. Appl. Environ. Microbiol. 66:4378-4382.

68. Summerell, B. A., Salleh, B., and Leslie, J. F. 2003. A utilitarian approach to Fusarium identification. Plant Dis. 87:117-128.

69. Sydenham, E. W., Shephard, G. S., and Thiel, P. G. 1992. Liquid chromatographic determination of fumonisin $\mathrm{B}_{1}, \mathrm{~B}_{2}$, and $\mathrm{B}_{3}$ in foods and feeds. $\mathrm{J}$. Assoc. Off. Anal. Chem. Intl. 75:313-318.

70. Thiel, P. G. 1990. Determination of moniliformin by high-performance liquid chromatography. J. Environ. Pathol. Toxicol. Oncol. 10:162-165.

71. Vos, P., Hogers, R., Bleeker, M., Reijans, M., van de Lee, T., Hornes, M., Frijters, A., Pot, J., Peleman, J., Kuiper, M., and Zabeau, M. 1995. AFLP: A new technique for DNA fingerprinting. Nucleic Acids Res. 23:44074414.

72. White, D. (ed.) 1999. Compendium of Corn Diseases. 3rd ed. The American Phytopathological Society, St. Paul, MN.

73. Wineland, G. O. 1924. An ascigerous stage and synonymy for Fusarium moniliforme. J. Agric. Res. 28:909-922.

74. Wollenweber, H. W., and Reinking, O. A. 1935. Die Fusarien, ihre Beschreibung, Schadwirkung und Bekämpfung. Paul Parey, Berlin, Germany.

75. Zeller, K. A., Jurgenson, J. E., El-Assiuty, E. M., and Leslie, J. F. 2000. Isozyme and amplified fragment length polymorphisms (AFLPs) from Cephalosporium maydis in Egypt. Phytoparasitica 28:121-130.

76. Zeller, K. A., Summerell, B. A., Bullock, S., and Leslie, J. F. 2003. Gibberella konza (Fusarium konzum) sp. nov., a new biological species within the Gibberella fujikuroi species complex from prairie grass. Mycologia 95:943-954. 